\title{
MODIFIED FIXED-ANGLE STRUT-AND-TIE MODEL FOR HIGH STRENGTH REINFORCED CONCRETE BEAMS
}

\author{
by Tavio ${ }^{1}$
}

\begin{abstract}
Nonlinear finite element analysis was applied to various reinforced concrete beams using a set of constitutive models established in the modified fixed-angle softened-truss model (MFA-STM). The model was implemented by modifying the general-purpose program FEAPpv. The model can take account of the six important characteristics of cracked reinforced concrete: (1) the softening effect of concrete in tension-compression; (2) the tension-stiffening effect of concrete in tension; (3) the average stress-strain curve of steel bars embedded in concrete; (4) the shear modulus of concrete; (5) the aggregate interlock; and (6) dowel action. The comparison shows the aggregate interlock and dowel action can reduce the overestimation of the shear capacity of high strength reinforced beam, especially the high strength reinforced deep beam without web reinforcement. Moreover, the model is suitable for being implemented numerical procedures due its simplicity.
\end{abstract}

KEYWORDS: high-strength concrete; shear; aggregate interlock; dowel action; finite element.

\section{INTRODUCTION}

The nonlinear finite element method has developed into an important tool for the analysis of the complex concrete structures. This technique is very helpful to understand the formation and propagation of cracks and the mechanism and process of failure. Future development of the nonlinear finite element method lies primarily in the improvements of the constitutive models of materials. Two behavioral models were developed for the analysis of concrete structures subjected to shear: the rotatingangle softened truss model (RA-STM) (1-3 $^{1-6}$ and the fixedangle softened truss model (FA-STM). ${ }^{3-6}$ The RA-STM assumes that cracks will develop in the direction parallel to the principal compressive stresses in concrete elements, and the cracks will "rotate" to follow the principal stresses over the entire loading history. In contrast, the FA-STM assumes that cracks will develop along the direction of principal compressive stresses at initial cracking, and the cracks will be "fixed" at this angle thereafter.

The advantage of FA-STM over RA-STM was that FA-STM was capable to take into account the concrete contribution, induced by the shear stresses along the cracks. Nevertheless, the FA-STM models average responses, without considering the specific contributions of the individual mechanical effects. In this paper, the FA-STM is modified by introducing the aggregate interlock and dowel action, which are used to control the average shear capability of concrete with cracks. In this paper, the incorporation of the set of modified FA-STM constitutive laws in to the computer code FEAPpv is described, and the comparison of the prediction of failure load of reinforced high strength concrete with the experimental results is given.

${ }^{1}$ Lecturer, Dept. of Civil Engineering, Sepuluh Nopember Institute of Technology (ITS), ITS Campus, Sukolilo, Surabaya 60111, Indonesia.

Note. The manuscript for this paper was submitted for review and possible publication on March 17, 2009; approved on October 26, 2009. Discussion open until February 2010. This paper is part of the ITS Journal of Civil Engineering, Vol. 29, No.1, May 2009. ( ) ITS Journal of Civil Engineering, ISSN 2086-1206/2009.

\section{DESCRIPTION OF MODEL}

\section{Equilibrium equations}

Assuming that the steel bars can resist only axial stresses, then the superposition of concrete stresses and steel stresses as shown in Fig. 1.

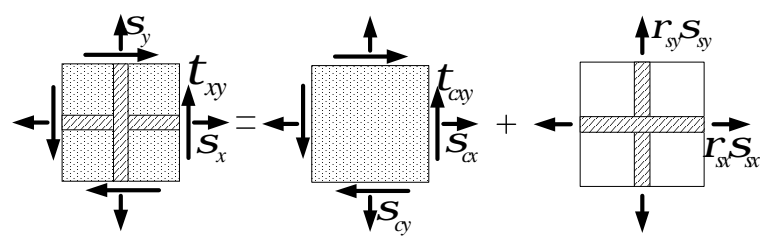

Fig. 1. Superposition of concrete stresses and steel stresses.

results in

$\begin{array}{ll}\sigma_{x}, \sigma_{y} & =\begin{array}{l}\text { Applied normal stress in the } \mathrm{x} \text { and } \mathrm{y} \\ \text { direction, respectively (positive for } \\ \text { tension) }\end{array} \\ \tau_{x y} & =\begin{array}{l}\text { Applied shear stress in the } \mathrm{x}-\mathrm{y} \\ \text { coordinate }\end{array} \\ \sigma_{c x}, \sigma_{c y} & =\begin{array}{l}\text { Average normal stress in concrete in } \\ \text { the x-y coordinate }\end{array} \\ \tau_{c x y} & =\begin{array}{l}\text { Average shear stress in concrete in } \\ \text { the X-y coordinate }\end{array} \\ \rho_{s x}, \rho_{s y} & =\begin{array}{l}\text { Reinforcement ratios in the x and } \mathrm{y}- \\ \text { direction, respectively }\end{array} \\ & \left\{\begin{array}{l}\sigma_{x} \\ \sigma_{y} \\ \tau_{x y}\end{array}\right\}=\left\{\begin{array}{l}\sigma_{c x} \\ \sigma_{c y} \\ \tau_{c x y}\end{array}\right\}+\left\{\begin{array}{c}\rho_{s x} \sigma_{s x} \\ \rho_{s y} \sigma_{s y} \\ 0\end{array}\right\}\end{array}$

where,

In the fixed-angle model, the $x^{\prime}-y^{\prime}$ coordinate system as shown in Fig. 2. is defined. In this coordinate system, $\mathrm{x}^{\prime}$ and $\mathrm{y}^{\prime}$ are the principal axes of stresses in concrete at initial cracking. Angle $\phi$ is the fixed angle between $\mathrm{x}$ and $\mathrm{x}^{\prime}$ axes. 


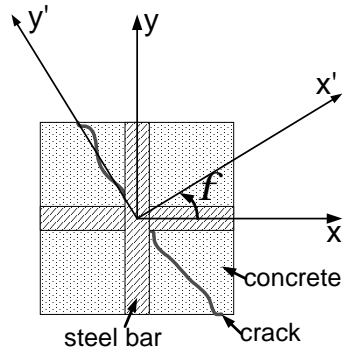

Fig. 2 Definition of coordinate systems and fixed angle.

The transformation of stresses in concrete from the $x^{\prime}-y^{\prime}$ to the $\mathrm{x}-\mathrm{y}$ coordinate system is given as follows:

$$
\left\{\begin{array}{l}
\sigma_{c x} \\
\sigma_{c y} \\
\tau_{c x y}
\end{array}\right\}=\left[\begin{array}{ccc}
c^{2} & s^{2} & 2 c s \\
s^{2} & c^{2} & -2 c s \\
-c s & c s & c^{2}-s^{2}
\end{array}\right]\left\{\begin{array}{c}
\sigma_{c x^{\prime}} \\
\sigma_{c y^{\prime}} \\
\tau_{c x^{\prime} y^{\prime}}
\end{array}\right\}
$$

where, $c=\cos (-\phi)$ and $s=\sin (-\phi)$. The stresses $\sigma_{c x^{\prime}}, \sigma_{c y^{\prime}}$ and $\tau_{c x^{\prime} y^{\prime}}$ are the stresses in concrete in $\mathrm{x}^{\prime}-\mathrm{y}^{\prime}$ coordinate system.

After introducing Eq. 2 into Eq. 1, the final expression for equilibrium condition for reinforced concrete can be obtained as:

$$
\left\{\begin{array}{l}
\sigma_{x} \\
\sigma_{y} \\
\tau_{x y}
\end{array}\right\}=\left[\begin{array}{ccc}
c^{2} & s^{2} & 2 c s \\
s^{2} & c^{2} & -2 c s \\
-c s & c s & c^{2}-s^{2}
\end{array}\right]\left\{\begin{array}{c}
\sigma_{c x^{\prime}} \\
\sigma_{c y^{\prime}} \\
\tau_{c x^{\prime} y^{\prime}}
\end{array}\right\}+\left\{\begin{array}{c}
\rho_{s x} \sigma_{s x} \\
\rho_{s y} \sigma_{s y} \\
0
\end{array}\right\}
$$

\section{Compatibility Equations}

Assuming that no slipping occurs between concrete and steel bars, the transformation of the average strains in reinforced concrete from the $x-y$ to the $x^{\prime}-y^{\prime}$ coordinate system is given as follows:

$$
\left\{\begin{array}{c}
\varepsilon_{x^{\prime}} \\
\varepsilon_{y^{\prime}} \\
\gamma_{x^{\prime} y^{\prime}}
\end{array}\right\}=\left[\begin{array}{ccc}
c^{2} & s^{2} & c s \\
s^{2} & c^{2} & -c s \\
-2 c s & 2 c s & c^{2}-s^{2}
\end{array}\right]\left\{\begin{array}{l}
\varepsilon_{x} \\
\varepsilon_{y} \\
\gamma_{x y}
\end{array}\right\}
$$

where, $c=\cos (\phi)$ and $s=\sin (\phi)$. The strains $\varepsilon_{x^{\prime}}, \varepsilon_{y^{\prime}}$ and $\gamma_{x^{\prime} y^{\prime}}$ are the strains in the $x^{\prime}-y^{\prime}$ coordinate system.

\section{Cracking Criterion}

The constitutive relationships of concrete must be guided by an interactive cracking criterion for concrete. A cracking criterion as shown in Fig. 3 is given as follows:

$$
\begin{gathered}
\frac{\sigma_{c 1}}{f_{t}}+0.3\left(\frac{\sigma_{c 2}}{\sigma_{c 1}}\right)^{2}=1, \text { tension-tension } \\
\left(\frac{\sigma_{c 1}}{f_{t}}\right)^{3}+\left(\frac{\left|\sigma_{2 c}\right|}{f_{c}^{\prime}}\right)=1, \text { tension-compression }
\end{gathered}
$$

$$
\left(\frac{\left|\sigma_{1 c}\right|}{f_{c}^{\prime}}+\frac{\left|\sigma_{2 c}\right|}{f_{c}^{\prime}}\right)^{2}-\frac{\left|\sigma_{2 c}\right|}{f_{c}^{\prime}}-3.65 \frac{\left|\sigma_{1 c}\right|}{f_{c}^{\prime}}=0,
$$

where $\sigma_{1 c}$ and $\sigma_{2 c}$ is the principal stress in concrete. The uniaxial tensile strength $f_{t}$ is defined as $0.058\left(10 f_{c}^{\prime}\right)^{2 / 3[10]}$

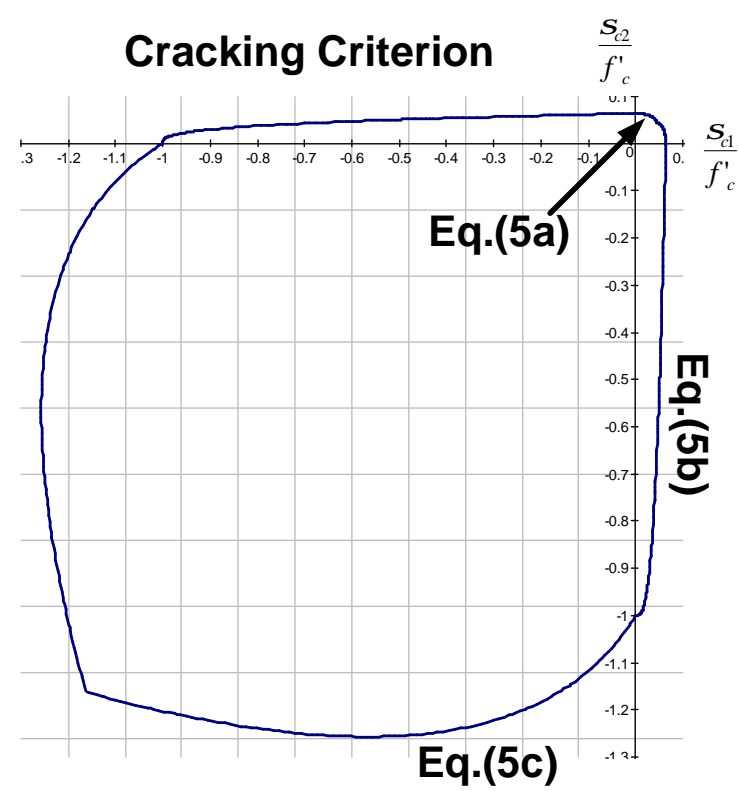

Fig. 3 Cracking surface.

As for the cracking envelope under biaxial stress, derived for the tension-compression domains and the Aoyagi-Yamada model ${ }^{7}$ for the domains of tensiontension together with the Kupfer's model $^{7}$ for the compression-compression domains are adopted.

\section{Constitutive Relationships Of Concrete Before Initial Cracking}

Before initial cracking, assuming that the principal direction of stress in concrete is coincide with the principal direction of strain, the constitutive relationships of concrete are given as follows:

$$
\begin{gathered}
\sigma_{1 c}=E_{c} \varepsilon_{1}, \text { tension } \\
\sigma_{2 c}=f_{c}^{\prime}\left[2\left(\frac{\varepsilon_{2}}{\varepsilon_{c}^{\prime}}\right)-\left(\frac{\varepsilon_{2}}{\varepsilon_{c}^{\prime}}\right)^{2}\right], \text { compression }
\end{gathered}
$$

where $E_{c}$ is the modulus of elasticity of concrete, $\varepsilon_{1}$ and $\varepsilon_{2}$ are the strains of concrete in the ascending and descending branches, respectively, and $\varepsilon_{c}^{\prime}$ is the strain of concrete at peak stress.

\section{Constitutive Relationships of Concrete After Initial Cracking}

After initial cracking, the constitutive relationships of concrete are established in the $\mathrm{x}^{\prime}-\mathrm{y}^{\prime}$ coordinate. 


\section{Concrete in compression-tension}

After initial cracking, the stress and strain softening occurs in concrete in compression-tension domains. The average stress-strain curve of concrete in compression $^{5,6,9}$ as shown in Fig. 4 is expressed as:

$$
\begin{aligned}
& \sigma_{c y^{\prime}}=\zeta f_{c}^{\prime}\left[2\left(\frac{\varepsilon_{y^{\prime}}}{\zeta \varepsilon_{c}^{\prime}}\right)-\left(\frac{\varepsilon_{y^{\prime}}}{\zeta \varepsilon_{c}^{\prime}}\right)^{2}\right], \varepsilon_{y^{\prime}} / \zeta \varepsilon_{c}^{\prime} \leq 1 \\
& \left.\sigma_{c y^{\prime}}=\zeta f_{c}^{\prime}\left[1-\left(\frac{\varepsilon_{y^{\prime}} / \zeta \varepsilon_{c}^{\prime}-1}{4 / \zeta-1}\right)^{2}\right], \frac{\varepsilon_{y^{\prime}} / \zeta \varepsilon_{c}^{\prime}>1}{}\right]
\end{aligned}
$$

where $f_{c}^{\prime}$ is the cylinder compression strength of concrete; $\varepsilon_{c}^{\prime}$ is the concrete strain at maximum compressive stress; and $\zeta$ is the softening coefficient. In the descending portion of the concrete stress-strain curve the lowest stresses value was taken as $0.2 \zeta f_{c}^{\prime}$ to avoid the potential numerical problem in calculation.

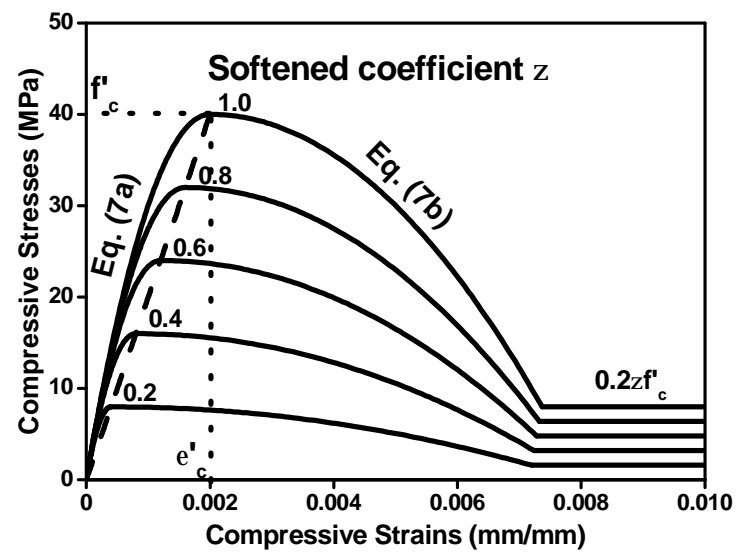

Fig. 4. Softened compressive stress-strain curve of concrete.

In Eq. (7a) and Eq. (7b), the stress-softened coefficient and the strain-softened coefficient are the same value of $\zeta$, which can be expressed conservatively as: ${ }^{5,6}$

$$
\begin{gathered}
\zeta=\frac{5.8}{\sqrt{f_{c}^{\prime}}} \frac{1}{\sqrt{1+\frac{400 \varepsilon_{x^{\prime}}}{\eta^{\prime}}}} \\
\eta=\frac{\rho_{s x} f_{s y Y}-\sigma_{y}}{\rho_{s y} f_{s x Y}-\sigma_{x}} \\
\eta^{\prime}=\eta, \eta \leq 1 \\
\eta^{\prime}=\frac{1}{\eta}, \eta>1
\end{gathered}
$$

where $\varepsilon_{x^{\prime}}$ is the tensile strain at $\mathrm{x}^{\prime}$-direction; $\rho_{s x}, \rho_{s y}$ are the reinforcement ratios in the $\mathrm{x}$ and $\mathrm{y}$ directions, respectively; $f_{s x Y}, f_{s y Y}$ are the yield stress of steel in the $\mathrm{x}$ and $y$ directions, respectively; and $\sigma_{x}, \sigma_{y}$ are the applied stresses in the $\mathrm{x}$ and $\mathrm{y}$ directions, respectively. The parameter $\eta^{\prime}$ is less than unity.

\section{Concrete in tension}

The average stress-strain curve of concrete in tension ${ }^{10}$ as shown in Fig. 5, can be expressed as:

$$
\begin{gathered}
\sigma_{c x^{\prime}}=E_{c} \varepsilon_{x^{\prime}}, \varepsilon_{x^{\prime}} \leq \varepsilon_{t} \\
\sigma_{c x^{\prime}}=f_{t}\left(\frac{\varepsilon_{t 0}}{\varepsilon_{x^{\prime}}}\right)^{0.4}, \varepsilon_{x^{\prime}}>\varepsilon_{t}, \text { for reinforced concrete } \\
\sigma_{c x^{\prime}}=f_{t}\left(\frac{\varepsilon_{t 0}}{\varepsilon_{x^{\prime}}}\right)^{1.2}, \varepsilon_{x^{\prime}}>\varepsilon_{t}, \text { for plain concrete }
\end{gathered}
$$

where $E_{c}$ is the modulus of elasticity of concrete; $f_{t}$ is the uniaxial tensile strength as defined in Eq. (5); $\varepsilon_{t 0}$ is the cracking strain of concrete, which equals to $\frac{f_{t}}{E_{c}}$

When concrete is cracked by tension, the tensile stress can drop fast. Especially in plain concrete, the tensile stress can change much faster than reinforced concrete because the crack in concrete can grow without the restriction by the reinforcing bars.

\section{Concrete in shear}

A rational shear modulus has been derived by $\mathrm{Zhu} .^{11}$ The average stress-strain relationship of concrete in shear can be expressed as:

$$
\tau_{c x^{\prime} y^{\prime}}=\frac{\sigma_{c x^{\prime}}-\sigma_{c y^{\prime}}}{2\left(\varepsilon_{x^{\prime}}-\varepsilon_{y^{\prime}}\right)}
$$

Transfer of shear forces across the crack surface in reinforced concrete member may result in a large sliding deformation and final failure by shear. Nevertheless, the model is "smeared". It models average responses, without considering the specific contributions of the individual mechanical effects, such as the aggregate interlock and dowel action at the crack location.

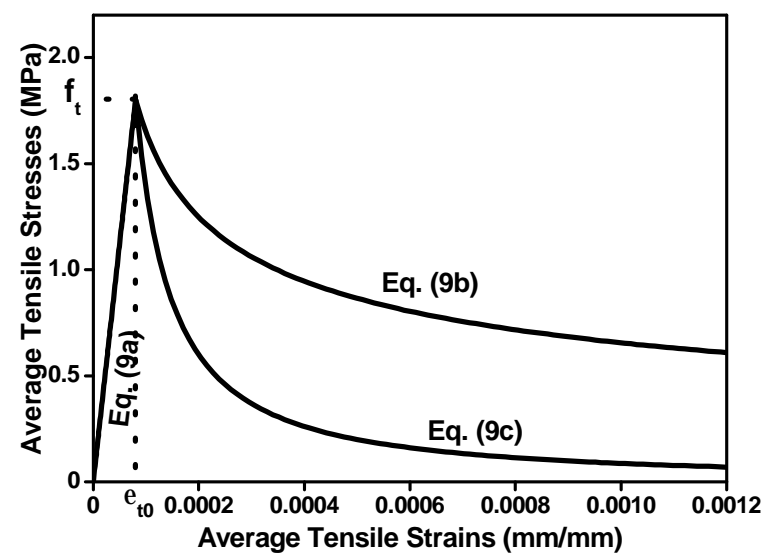

Fig. 5. Average tensile stress-strain curve of concrete.

\section{Aggregate Interlock}

Sliding shear deformations at the cracks in reinforced concrete structures are resisted by the aggregate interlock resulting from roughness of the crack faces. Aggregate interlock force is a major factor attributed by concrete in the analysis of shear behaviors in reinforced concrete 
beams. This is mainly due to their significant contribution in shear transfer along crack interface of reinforced concrete. It is known that at the cracks of a reinforced concrete element subjected to in-plane loads, only steel forces are initially developed. Aggregate interlock forces are produced later to help steel forces sustain the external loads.

Many experimental investigations have been carried out for aggregate interlock. Based on both test results and the physical concepts of aggregate interlock behavior, Bazant and Gambarova ${ }^{12}$ developed a more comprehensive model. Unlike previous studies, their model accounts for the facts discovered in the test: (1) at zero sliding-shear deformation, no normal stress exists across an open crack; (2) at a constant value of slidingshear deformation, the shear stress tend to decrease as the crack opening increases; (3) the shear stresses tend to increase with increasing sliding-shear defor-mation at a constant crack width. Their ex-pressions for aggregate interlock are shown here:

$$
\begin{gathered}
\tau_{a}=0.245 f_{c}^{\prime} \frac{0.01 D^{2}}{0.01 D^{2}+\delta_{n}^{2}} r \\
\frac{10 / f_{c}^{\prime}+2.44\left(1-16.31 / f_{c}^{\prime}\right)|r|^{3}}{1+2.44\left(1-16.31 / f_{c}^{\prime}\right) r^{4}}
\end{gathered}
$$

where, $f_{c}^{\prime}$ is the uniaxial compressive strength of concrete; $\delta_{n}$ is the crack opening; $\delta_{t}$ is the crack slip; $r=\delta_{t} / \delta_{n}$; and $D$ is the maximum aggregate size (mm).

In concrete containing many parallel cracks, the deformations due to the cracks may be considered continuously distributed or smeared. The opening and slip of the crack can be expressed in the form of average strains due to the smeared cracks (see Fig. 6):

$$
\begin{gathered}
\delta_{n}=w=\varepsilon_{x^{\prime}} l_{s} \\
\delta_{t}=\gamma_{x^{\prime} y} l_{s}
\end{gathered}
$$

where, $\varepsilon_{x^{\prime}}$ is the average strain at the crack normal direction; and $\gamma_{x^{\prime} y^{\prime}}$ is the average shear strain at the crack direction.

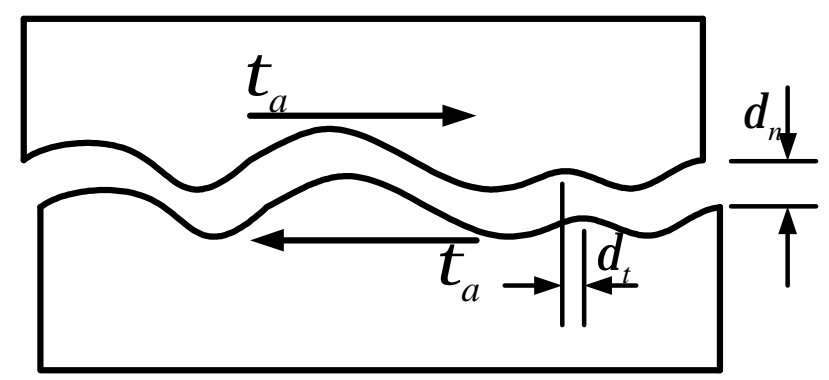

Fig. 6. Meaning of Symbols in Eq. (11).

Here $l_{s}$ is the average spacing of the diagonal cracks which is calculated from the CEB-FIP Code:

$$
l_{s}=\left(\frac{\cos \phi}{l_{s x}}+\frac{\sin \phi}{l_{s y}}\right)^{-1}
$$

where, $\phi$ is the initial cracking angle between the $\mathrm{x}$ direction reinforcement and the direction of the initial cracking principal tensile stress (see Fig. 2); and $l_{s x}, l_{s y}$ are the crack spacing in the two orthogonal directions. The values of $l_{s x}, l_{s y}$ are estimated as:

$$
\begin{aligned}
& l_{s x}=2\left(c_{x}+\frac{s_{x}}{10}\right)+\frac{0.25 k D_{x}}{\rho_{s x}} \\
& l_{s y}=2\left(c_{y}+\frac{s_{y}}{10}\right)+\frac{0.25 k D_{y}}{\rho_{s y}}
\end{aligned}
$$

The meanings of the symbols in above equations are shown in Fig. 7. The symbol $s_{y}$ is the spacing of web reinforcement, and $\rho_{s x}, \rho_{s y}$ are the reinforcement ratios of $x$ - and $y$-directions. $k$ is a characteristic factor of reinforcement and taken as 0.4 for deformed bars or 0.8 for plain bars or bonded strands.

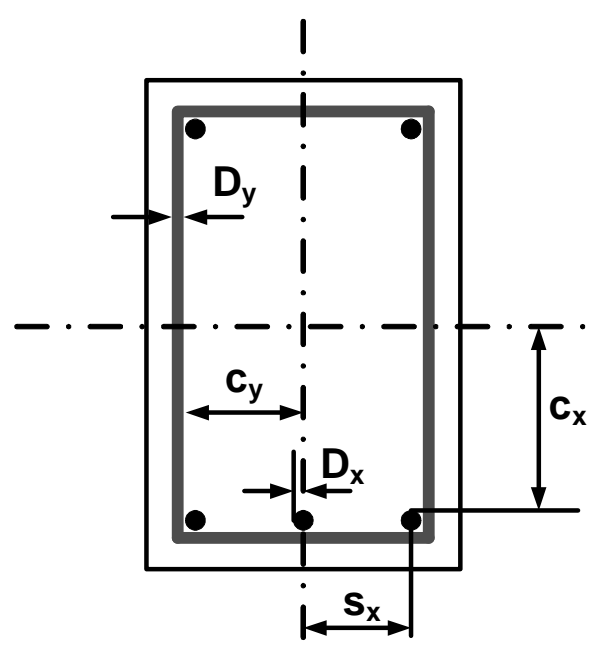

Fig. 7. Meaning of Symbols in Eq. 14a and 14b.

Based on Bazant's rough cracks model, by optimizing the fits of Paulay and Loeber's test data ${ }^{13}$ and of Daschner and Kupfer's test data, ${ }^{14}$ and by assuming for crack roughness the aggregate grading suggested by Fuller's curve, the following equation was formulated: ${ }^{15}$

$$
\begin{aligned}
& \tau_{a}=0.25 f_{c}^{\prime}\left(1+\sqrt{\frac{2 \delta_{n}}{D}}\right) r \\
& \frac{9.8 / f_{c}^{\prime}+2.44\left(1-16 / f_{c}^{\prime}\right)|r|^{3}}{1+2.44\left(1-16 / f_{c}^{\prime}\right) r^{4}}
\end{aligned}
$$

where, $r, \delta_{t}$ and $\delta_{n}$ have the same meanings as Bazant's equation. However, by comparison with the experimental data, it is found that the Eq. 15a may overestimate the aggregate interlock of high strength concrete. In the proposed model, the equation of aggregate interlock is modified to; 


$$
\begin{aligned}
& \tau_{a}=0.04 f_{c}^{\prime}\left(1+\sqrt{\frac{2 \delta_{n}}{D}}\right) r \\
& \frac{9.8 / f_{c}^{\prime}+2.44\left(1-16 / f_{c}^{\prime}\right)|r|^{3}}{1+2.44\left(1-16 / f_{c}^{\prime}\right) r^{4}}
\end{aligned}
$$

\section{Dowel Action at the Crack Location}

Dowel action is one of the main mechanisms of load transfer along reinforced concrete interfaces. There are two possible failure modes of the dowel mechanism. One is due to yielding of the dowel bar and the crushing under the dowel, the other one is due to the concrete splitting. Generally, concrete cover $c$ is the main parameter upon which the mode of the failure of the dowel mechanism depends.

The previous experimental investigations ${ }^{16}$ have shown that when $c$ is greater than 6 to 7 time the bar diameter, failure is controlled by the crushing of concrete and the yielding of the bar. For smaller concrete cover, the failure mechanism is governed by splitting of the concrete, and the splitting cracks can be opened at the bottom or at the side faces of the section. In a reinforced concrete element or a beam, the two directions reinforcement is usually arranged along the brim of the cross section, thus these bars have smaller side covers, and dowel failure occurring in these structural members belongs to the concrete splitting.

In previous work, ${ }^{17,2}$ the existence of the shear forces due to dowel action was neglected, and this underestimated the role of the steel. In this present research, the shear contributions from dowel action are considered until the final collapse of the element.

Generally, the dowel action and aggregate interlock have some common characteristics. They both occur at the crack location in order to replace the lost stress in the steel and concrete. Both are transmitted to the bulk of the concrete, and therefore, they are in fact concrete forces.

For the prediction of the dowel action when failure is due to the concrete splitting, only the empirical equations are available. Eq. 16 was developed by Baumann and Ruch $^{17}$.

$$
D_{u}=1.64 b_{n} d_{b} \sqrt[3]{f_{c}^{\prime}} \text { in } \mathrm{N}, \mathrm{mm}
$$

where, $b_{n}$ is the net width of beam and $d_{b}$ is the diameter of the dowel bar (see Fig. 8).

The average stresses should be limited by the stresses at the crack. Therefore, the average shear stress should be controlled by the local shear stress contributed by the aggregate interlock and dowel action.

$$
\left|\tau_{x^{\prime} y^{\prime}}\right| \leq\left|\tau_{a}\right|+\left(\left|D_{x} \sin \varphi\right|+\left|D_{y} \cos \varphi\right|\right) / b d_{v}
$$

where, $D_{x}, D_{y}$ are the dowel action of all of $\mathrm{y}$ - of $\mathrm{x}$ direction bars, respectively, $b$ is the width of a rectangular beam, $d_{v}$ is the depth of effective shear element, and $\phi$ is the initial cracking angle.

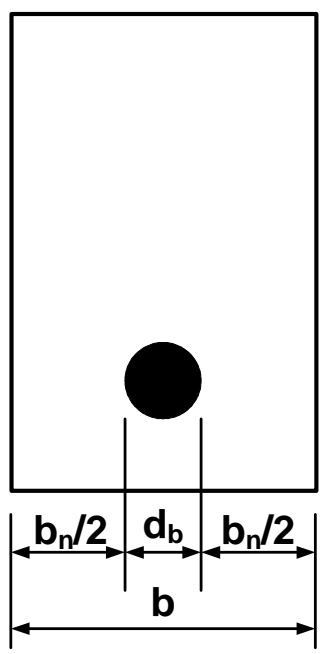

Fig. 8. Meaning of Symbols in Eq. 16.

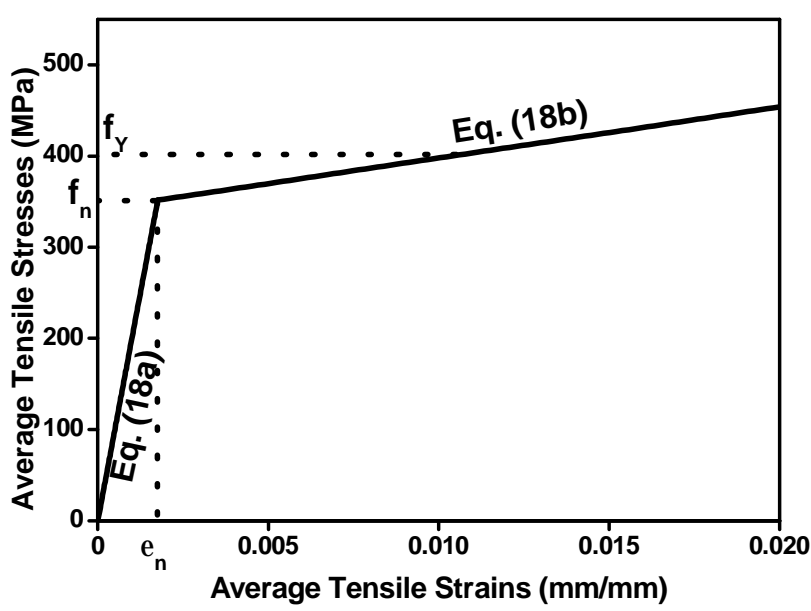

Fig. 9 Average stress-strain curve of steel bars embedded in concrete.

\section{Constitutive relationship of steel bar}

The stress-strain curve of steel can be modeled by two straight lines, ${ }^{2,4,10}$ as shown in Fig. 9. The bilinear model is given as follows:

$\sigma_{s}=E_{s} \varepsilon_{s}, \varepsilon_{s} \leq \varepsilon_{n}$
$\sigma_{s}=f_{Y}\left[(0.91-2 B)+(0.02+0.25 B) \frac{\varepsilon_{s}}{\varepsilon_{y}}\right], \varepsilon_{s}>\varepsilon_{n}$

where $B$ is a parameter defined as $(1 / \rho)\left(f_{c r} / f_{Y}\right)^{1.5}$, and $\varepsilon_{n}$ is the average yield strain of mild steel bars embedded in concrete at the beginning of yielding, taken as $\varepsilon_{Y}(0.93-2 B)$.

\section{Test Program}

Eighteen simply supported reinforced high-strength concrete beams were to be tested under two-point loading. It is already known that the thickness of the beams has no contribution to size effect, so all test beams were chosen to have the same width of $185 \mathrm{~mm}$. The test beams were divided into two series with different $a / d$ ratio of 2 and 3.5 . 
Table 1. Details of 18 experimental beams

\begin{tabular}{|c|c|c|c|c|c|c|c|c|c|c|c|c|c|c|c|}
\hline \multirow[t]{2}{*}{ Groups } & \multirow[t]{2}{*}{$\begin{array}{c}\text { Beam } \\
\text { Notations }\end{array}$} & \multicolumn{5}{|c|}{ Beam dimension } & \multicolumn{2}{|c|}{ Concrete strength } & \multicolumn{2}{|c|}{ Steel strength } & \multicolumn{2}{|c|}{$\begin{array}{l}\text { Main tension } \\
\text { reinforcement }\end{array}$} & \multicolumn{3}{|c|}{$\begin{array}{l}\text { Vertical web } \\
\text { reinforcement }\end{array}$} \\
\hline & & $\begin{array}{c}\mathrm{b} \\
\mathrm{mm}\end{array}$ & $\begin{array}{c}\mathrm{h} \\
(\mathrm{mm})\end{array}$ & $\begin{array}{c}\mathrm{d} \\
(\mathrm{mm})\end{array}$ & $\begin{array}{c}\mathrm{a} \\
(\mathrm{mm})\end{array}$ & $\begin{array}{c}1 \\
(\mathrm{~mm}) \\
\end{array}$ & $\begin{array}{c}\mathrm{fc}^{\prime} \\
\mathrm{MPa} \\
\end{array}$ & Batch & $\begin{array}{c}\text { fys } \\
\mathrm{MPa}\end{array}$ & $\begin{array}{l}\text { fyv } \\
\mathrm{MPa}\end{array}$ & $\begin{array}{c}\text { As } \\
\mathrm{mm} 2 \\
\end{array}$ & $\begin{array}{l}\rho \\
\% \\
\end{array}$ & $\begin{array}{c}\mathrm{Av} \\
\mathrm{mm} 2 \\
\end{array}$ & $\begin{array}{c}\mathrm{s} \\
\mathrm{mm} \\
\end{array}$ & $\begin{array}{r}\rho v \\
\% \\
\end{array}$ \\
\hline \multicolumn{16}{|c|}{ Series 1} \\
\hline \multirow{4}{*}{1} & B-2-200 & 185 & 250 & 200 & 400 & 1300 & 89 & 1 & 512 & 0 & 1480 & 3.98 & - & - & 0 \\
\hline & B-2-400 & 185 & 475 & 400 & 800 & 2600 & 95 & 1 & 512 & 0 & 2960 & 3.98 & - & - & 0 \\
\hline & B-2-700 & 185 & 825 & 700 & 1400 & 4550 & 92 & 3 & 512 & 0 & 5180 & 3.98 & - & - & 0 \\
\hline & V-2-200 & 185 & 250 & 200 & 400 & 1300 & 75 & 4 & 512 & 518 & 1480 & 3.98 & 57 & 91 & 0.34 \\
\hline \multirow[t]{3}{*}{2} & $V-2-400$ & 185 & 475 & 400 & 800 & 2600 & 95 & 1 & 512 & 518 & 2960 & 3.98 & 157 & 250 & 0.34 \\
\hline & V-2-700 & 185 & 825 & 700 & 1400 & 4550 & 98 & 3 & 512 & 518 & 5180 & 3.98 & 157 & 250 & 0.34 \\
\hline & VV-2-200 & 185 & 250 & 200 & 400 & 1300 & 75 & 4 & 512 & 518 & 1480 & 3.98 & 157 & 150 & 0.57 \\
\hline \multirow[t]{4}{*}{3} & VV-2-400 & 185 & 475 & 400 & 800 & 2600 & 95 & 1 & 512 & 518 & 2960 & 3.98 & 157 & 150 & 0.57 \\
\hline & VV-2-700 & 185 & 825 & 700 & 1400 & 4550 & 98 & 3 & 512 & 518 & 5180 & 3.98 & 157 & 150 & 0.57 \\
\hline & & & & & & & & & & & & & & & \\
\hline & B-3.5-200 & 185 & 250 & 200 & 700 & 1900 & 85 & 2 & 512 & 0 & 1480 & 3.98 & - & - & 0 \\
\hline \multirow[t]{3}{*}{1} & B-3.5-400 & 185 & 475 & 400 & 1400 & 3800 & 85 & 2 & 512 & 0 & 2960 & 3.98 & - & - & 0 \\
\hline & B-3.5-700 & 185 & 825 & 700 & 2450 & 6650 & 102 & 1 & 512 & 0 & 5180 & 3.98 & - & - & 0 \\
\hline & $V-3.5-200$ & 185 & 250 & 200 & 700 & 1900 & 85 & 2 & 512 & 518 & 1480 & 3.98 & 57 & 91 & 0.34 \\
\hline \multirow[t]{3}{*}{2} & $V-3.5-400$ & 185 & 475 & 400 & 1400 & 3800 & 85 & 2 & 512 & 518 & 2960 & 3.98 & 157 & 250 & 0.34 \\
\hline & V-3.5-700 & 185 & 825 & 700 & 2450 & 6650 & 102 & 1 & 512 & 518 & 5180 & 3.98 & 157 & 250 & 0.34 \\
\hline & VV-3.5-200 & 185 & 250 & 200 & 700 & 1900 & 85 & 2 & 512 & 518 & 1480 & 3.98 & 157 & 150 & 0.57 \\
\hline \multirow[t]{2}{*}{3} & VV-3.5-400 & 185 & 475 & 400 & 1400 & 3800 & 85 & 2 & 512 & 518 & 2960 & 3.98 & 157 & 150 & 0.57 \\
\hline & VV-3.5-700 & 185 & 825 & 700 & 2450 & 6650 & 104 & 1 & 512 & 518 & 5180 & 3.98 & 157 & 150 & 0.57 \\
\hline
\end{tabular}

Notations: B-2-200 = "B" means beams without web reinforcement; 2 means $a / d$ ratio of 2; 200 is effective depth,; "V" means beams with web reinforcement percentage of 0.34 , "VV" means beams with web reinforcement percentage of 0.57 , etc. $b$-- width of the beam, $h$-- overall depth of beam, $d$-- effective depth of beam, $a$-shear span, $l$-- overall length of beam, $\rho$-- main tension steel ratio, $\rho_{v}$-- web reinforcement ratio.

Table 2. Cracking loads, ultimate Loads and failure modes of 18 concrete beams

\begin{tabular}{|c|c|c|c|c|c|c|c|}
\hline \multirow{2}{*}{$\begin{array}{c}\text { No. } \\
\text { of } \\
\text { Beams }\end{array}$} & \multirow{2}{*}{$\begin{array}{c}\text { Beam } \\
\text { Notations }\end{array}$} & \multicolumn{2}{|c|}{ Cracking Stress (MPa) } & \multirow{2}{*}{$\begin{array}{c}\text { Ultimate } \\
\text { Stress (Mpa) } \\
\text { vu }\end{array}$} & \multirow{2}{*}{$\begin{array}{c}\text { Modes } \\
\text { of } \\
\text { Failure }\end{array}$} & \multicolumn{2}{|c|}{ Ratios of Loads } \\
\hline & & $\begin{array}{c}\text { Flexural } \\
\text { vf }\end{array}$ & $\begin{array}{c}\text { Diagonal } \\
\text { vd }\end{array}$ & & & $\mathrm{vf} / \mathrm{vu}$ & $\mathrm{vd} / \mathrm{vu}$ \\
\hline 1 & B-2-200 & 0.68 & 2.03 & 6.28 & DS & 0.10 & 0.32 \\
\hline 2 & V-2-200 & 0.41 & 2.03 & 7.57 & DS & 0.05 & 0.27 \\
\hline 3 & VV-2-200 & 0.54 & 2.7 & 8.23 & $\mathrm{CC}$ & 0.07 & 0.33 \\
\hline 4 & B-3.5-200 & 0.41 & 1.89 & 1.89 & DT & 0.22 & 1.00 \\
\hline 5 & V-3.5-200 & 0.27 & 1.62 & 4.32 & DT & 0.06 & 0.38 \\
\hline 6 & VV-3.5-200 & 0.41 & 1.89 & 4.69 & $\mathrm{CC}$ & 0.09 & 0.40 \\
\hline 7 & B-2-400 & 0.74 & 1.89 & 6.49 & DS & 0.11 & 0.29 \\
\hline 8 & V-2-400 & 0.95 & 2.03 & 8.11 & DS & 0.12 & 0.25 \\
\hline 9 & VV-2-400 & 0.95 & 2.36 & 8.23 & $\mathrm{CC}$ & 0.12 & 0.29 \\
\hline 10 & B-3.5-400 & 0.27 & 1.82 & 1.82 & DT & 0.15 & 1.00 \\
\hline 11 & $V-3.5-400$ & 0.41 & 1.22 & 5.03 & DT & 0.08 & 0.24 \\
\hline 12 & VV-3.5-400 & 0.41 & 1.62 & 5.07 & $\mathrm{CC}$ & 0.08 & 0.32 \\
\hline 13 & B-2-700 & 0.77 & 1.54 & 4.44 & DS & 0.17 & 0.35 \\
\hline 14 & $\mathrm{~V}-2-700$ & 0.62 & 1.54 & 6.22 & DS & 0.10 & 0.25 \\
\hline 15 & VV-2-700 & 0.62 & 1.54 & 7.61 & $\mathrm{SC}$ & 0.08 & 0.20 \\
\hline 16 & B-3.5-700 & 0.39 & 1.54 & 1.54 & DT & 0.25 & 1.00 \\
\hline 17 & V-3.5-700 & 0.39 & 1.54 & 4.4 & DT & 0.09 & 0.35 \\
\hline 18 & VV-3.5-700 & 0.46 & 1.54 & 4.79 & $\mathrm{CC}$ & 0.10 & 0.32 \\
\hline
\end{tabular}

* Notations: DS - diagonal splitting failure; DT - diagonal-tension failure; FC - flexural failure in compression zone; SC - shear compression

In each series, three groups of beams were cast according to the different percentages of web preinforcement. In each group the effective depths of the specimens were varied from 200 to $700 \mathrm{~mm}$, whereas all other variables remained constant. The specimen dimensions and other parameters are given in Table 1.
The beams were geometrically scaled appropriately in all respects (see Fig. 10) except the maximum aggregate size which is maintained at $20 \mathrm{~mm}$. Previous investigation by Walraven and Lehwalter ${ }^{19}$ indicated that there was no significant influence of the maximum aggregate size on the size effect in shear behavior. All of the specimens were designed to fail in shear as far as possible. 


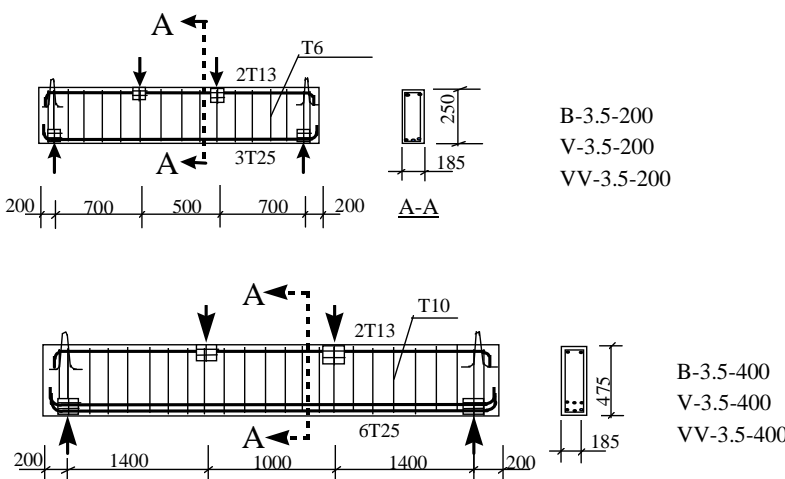

$\underline{\mathrm{A}-\mathrm{A}}$

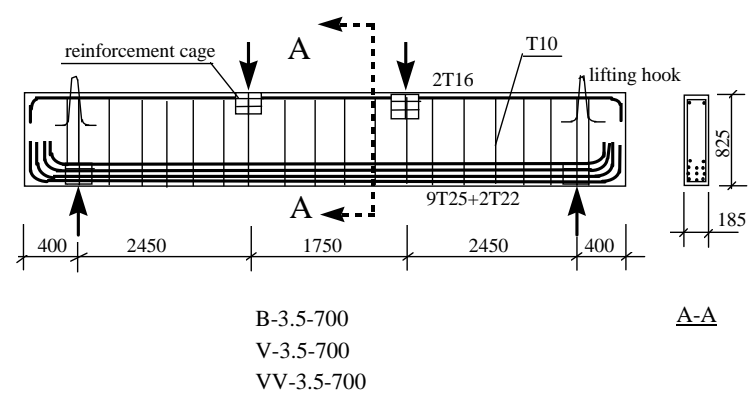

Notes: Three beams for each figure. one beam without stirrups,

one beam with T10 stirrups at spacing $250 \mathrm{~mm}$, or T6 at spacing $90 \mathrm{~mm}$

one beam with T10 stirrups at spacing $150 \mathrm{~mm}$.

Same details were also used with $a / d$ of 2 beams

Fig. 10. Details of beam specimens.

\section{Materials}

The compressive strength of the concrete was designed to be about $100 \mathrm{MPa}$ for all the beam specimens. The slump of the mix was about $200 \mathrm{~mm}$. Two $150 \times 150$ $\times 150 \mathrm{~mm}$ concrete cubes and two $150 \times 300 \mathrm{~mm}$ concrete cylinders were cast and tested together with each specimen to obtain the compressive strength of concrete, $f_{c u}$ and $f_{c}^{\prime}$. Since the beams were cast in different batches, regression analyses were carried out for concrete compressive strength in each batch. Different average concrete strength of each beam specimen was then obtained from the results of these regression curves according to the age of specimen at the time of testing. The results are given in Table 1 .

There are two types of reinforcement bars used in the beam specimens: deformed high tensile steel ( $\mathrm{T}$ bar) and plain round mild steel ( $\mathrm{R}$ bar). The average yield stresses of the steels used in the specimens are tabulated in Table 1. Note that T10 indicates a T bar of $10 \mathrm{~mm}$ diameter, etc.

\section{Test set-up}

The typical set-up for specimens is shown in Fig. 11. The test specimens were loaded by two $1000 \mathrm{kN}$ actuators. Before testing, each specimen was white-washed on one surface and $150 \mathrm{~mm} \times 150 \mathrm{~mm}$ grids were drawn in pencil to facilitate crack detection. Deflections of the beam specimens were measured using Linear Voltage Displacement Transducers (LVDTs) located at the bottom central line of the beams at seven locations.

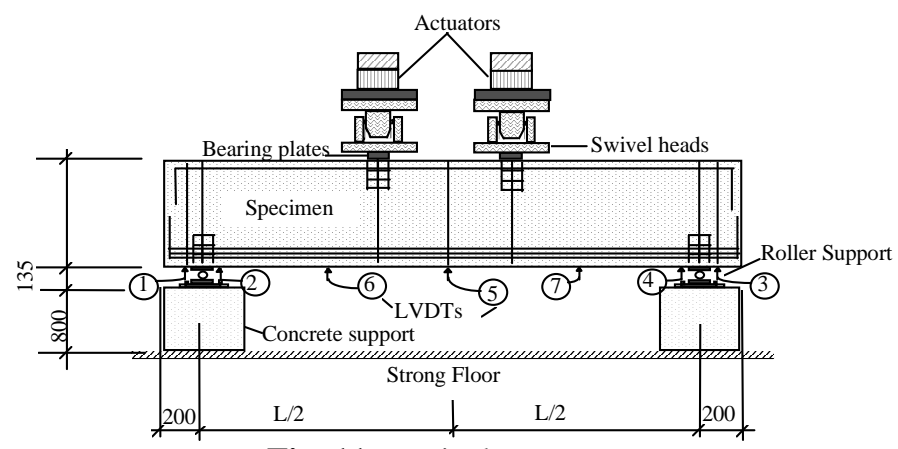

Fig. 11. Typical test set-up.

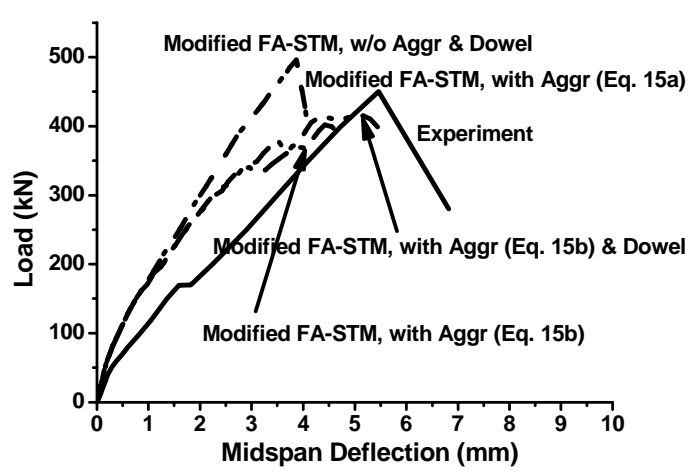

(a) B-2-200

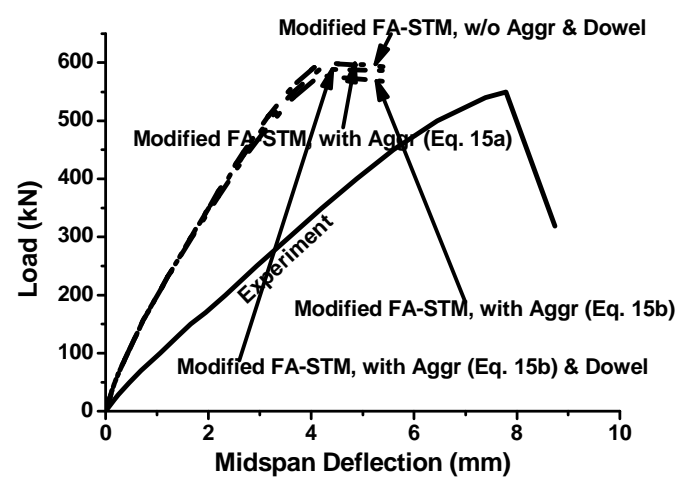

(b) $\mathrm{V}-2-200$

Fig. 12. Load-displacement relations of slender beams with $d=200 \mathrm{~mm}$

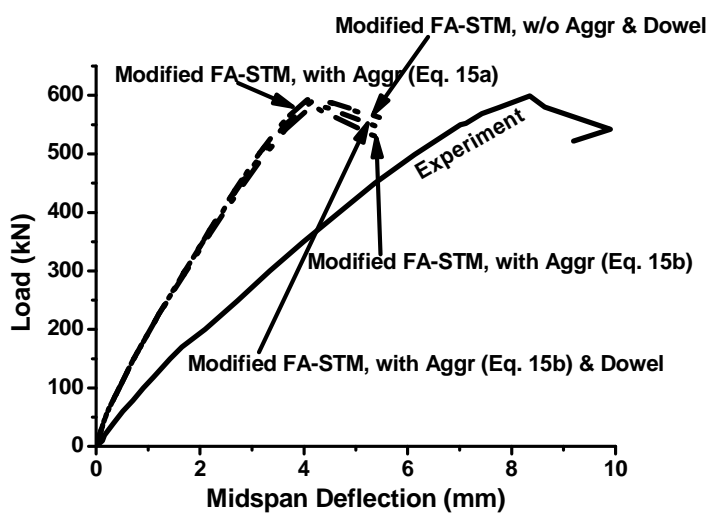

(c) VV-2-200

Fig. 12. Load-displacement relations of slender beams with $d=200 \mathrm{~mm}$ (continued). 


\section{COMPARISON BETWEEN THEORETICAL ANALYSIS AND EXPERIMENTAL DATA}

To verify the reliability of the proposed method, the 18 beams are analyzed as shown in Table 2. The comparisons between the proposed model and the experimental data are shown in Figs. 12-17 that show the relationship between the load and midspan deflection.

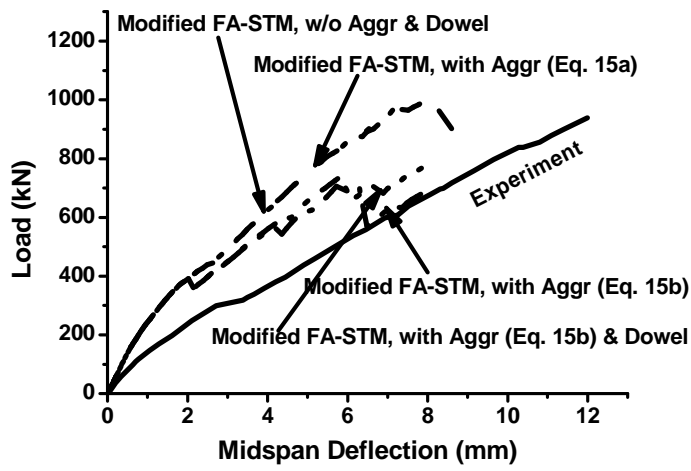

(a) B-2-400

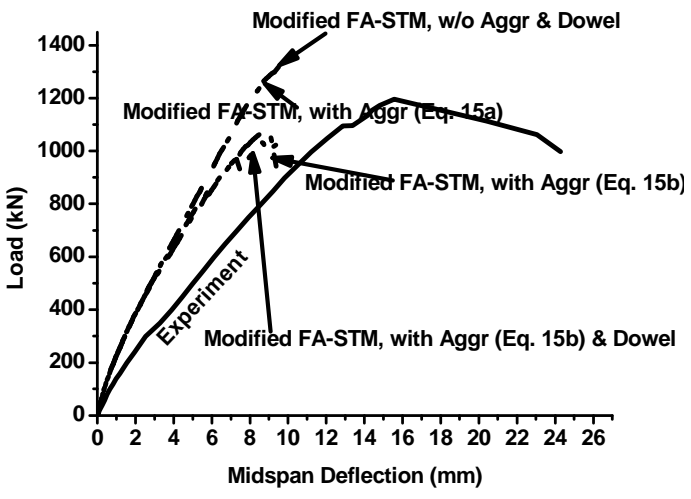

(b) $\mathrm{V}-2-400$

Fig. 13. Load-displacement relations of slender beams with $d=400 \mathrm{~mm}$

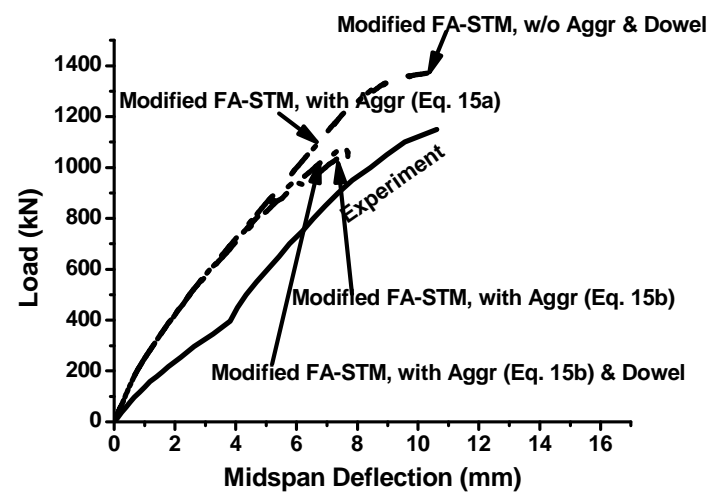

(c) VV-2-400

Fig. 13. Load-displacement relations of slender beams with $d=400 \mathrm{~mm}$ (continued).
The calculation was terminated when the average shear strain in the element reaches $1.0 \%$. It was found that the shear strain increases suddenly afterwards, leading to failure. In these figures, it is found that the loaddisplacement curves calculated by the model without considering the aggregate interlock and dowel action almost coincide with the curves calculated by the model with considering the aggregate interlock using Eq. 15a. Eq. 15a may overestimate the aggregate interlock of high strength concrete, especially for the high strength concrete deep beams without web reinforcement as shown in Fig. 15(a), Fig. 16(a) and Fig. 17(a). So Eq. 15a is changed into Eq. $15 \mathrm{~b}$ to reduce the overestimation of aggregate interlock.

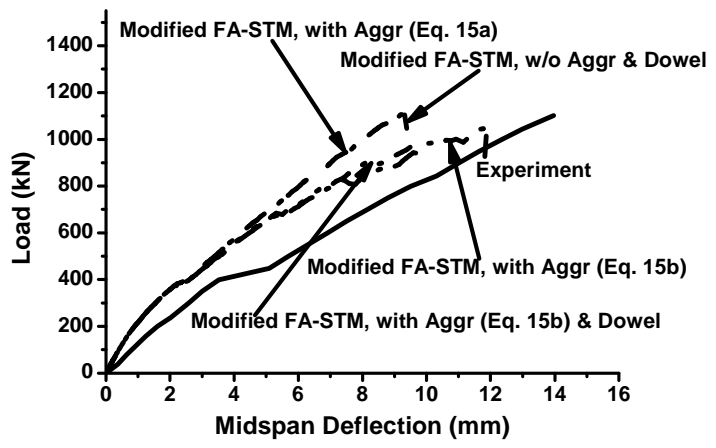

(a)B-2-700

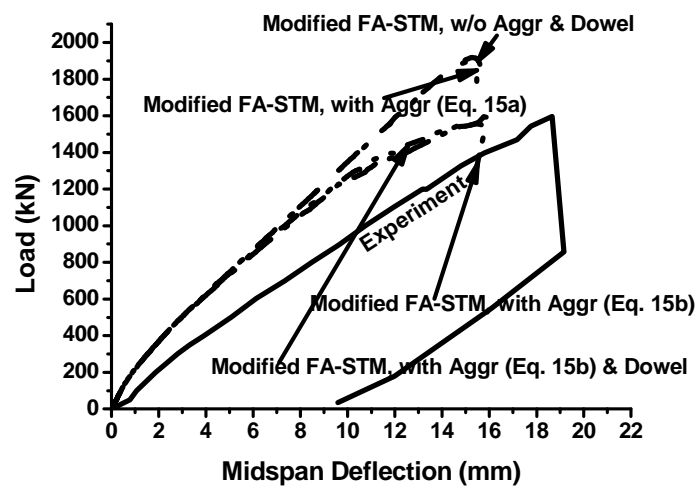

(b) V-2-700

Fig. 14. Load-displacement relations of slender beams with $d=700 \mathrm{~mm}$

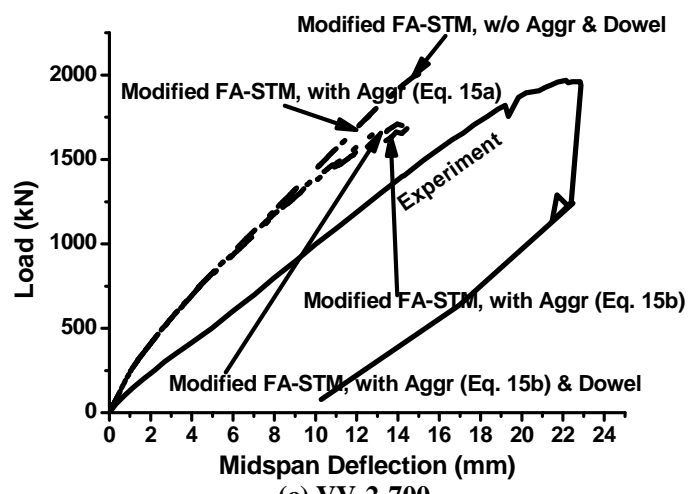

(c) VV-2-700

Fig. 14. Load-displacement relations of slender beams with $d=700 \mathrm{~mm}$ (continued). 


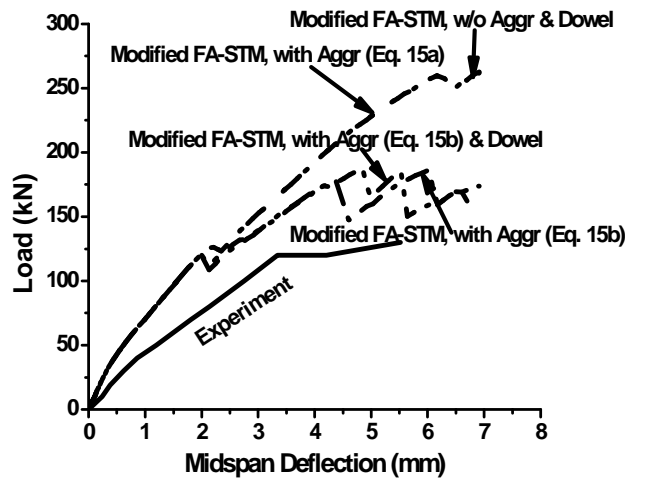

(a) B-3.5-200

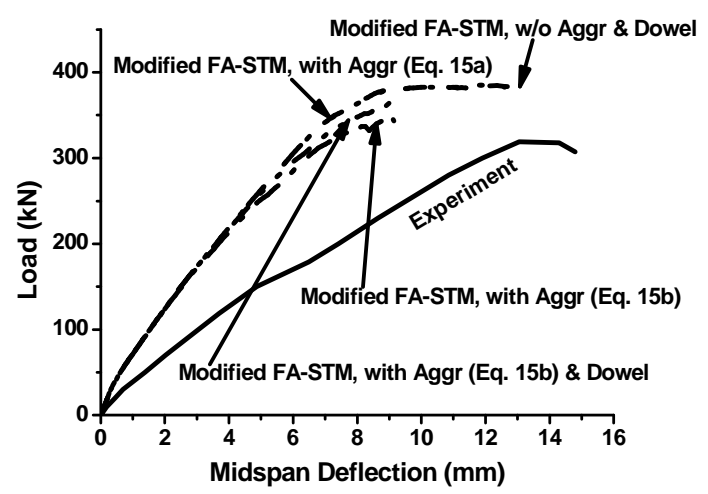

(b) V-3.5-200

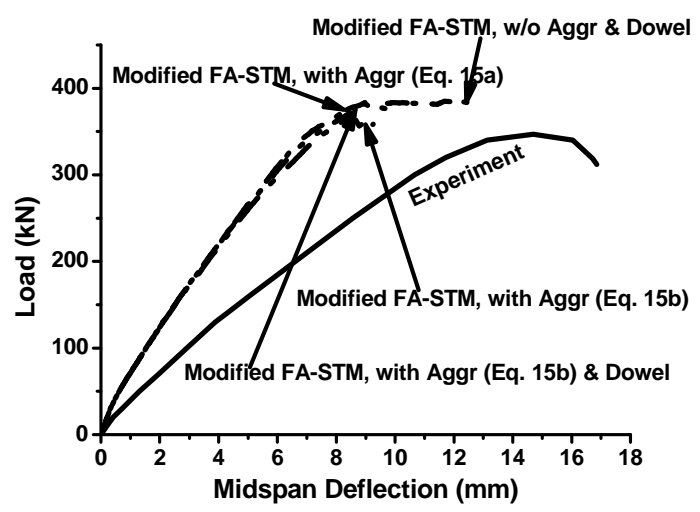

(c) VV-3.5-200

Fig. 15. Load-displacement relations of deep beams with $d=200 \mathrm{~mm}$

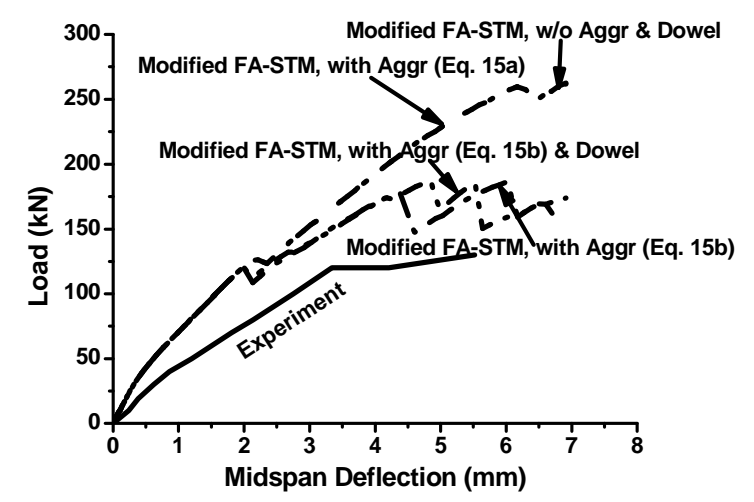

(a) B-3.5-200

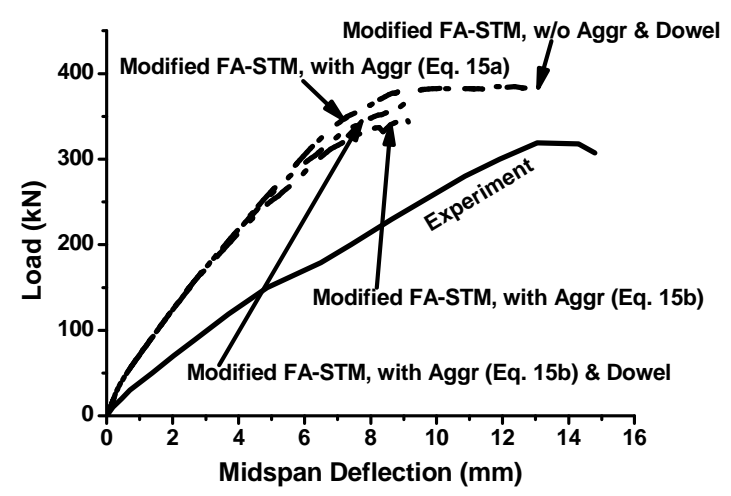

(b) V-3.5-200

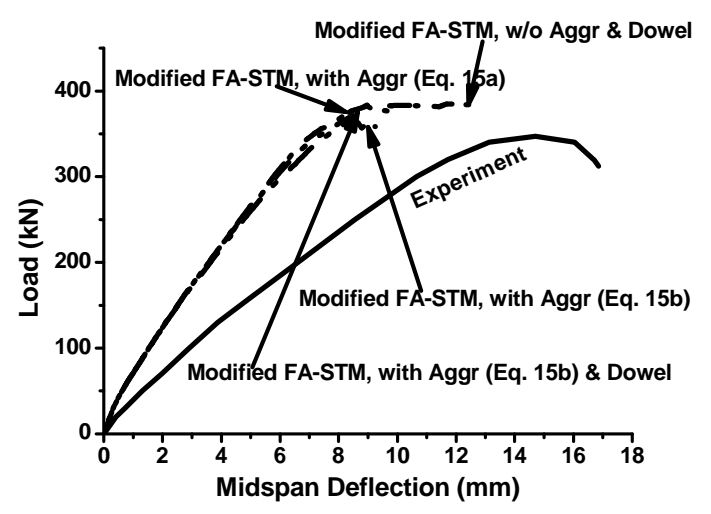

(c) VV-3.5-200

Fig. 16. Load-displacement relations of deep beams with $d=400 \mathrm{~mm}$

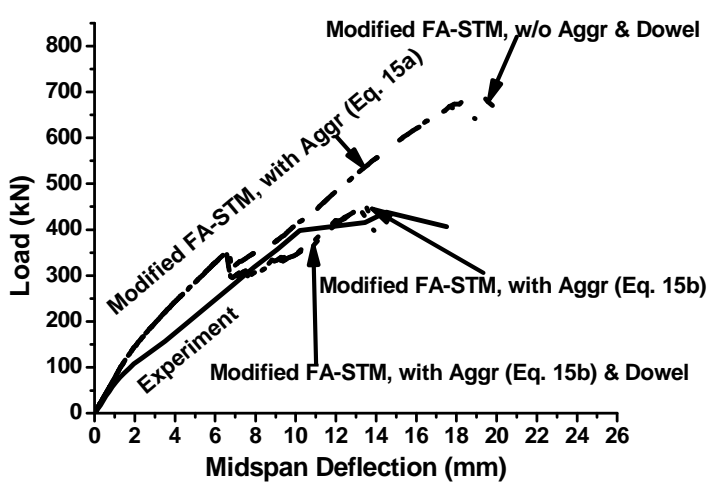

(a) B-3.5-700

Fig. 17. Load-displacement relations of deep beams with $d=700 \mathrm{~mm}$

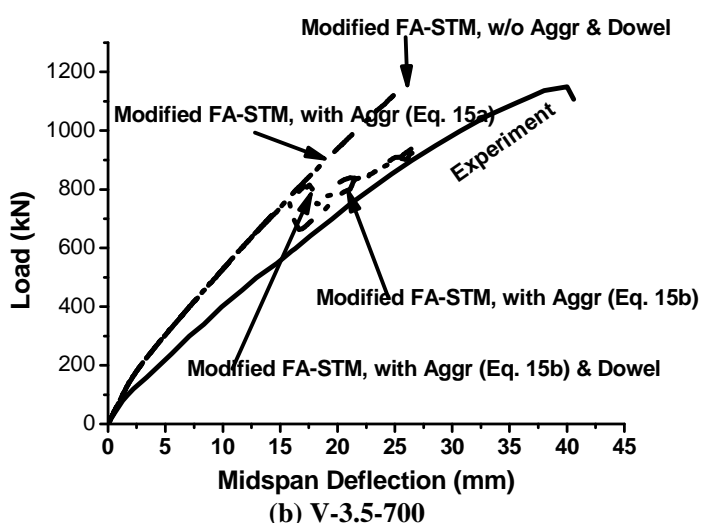

(b) V-3.5-700 


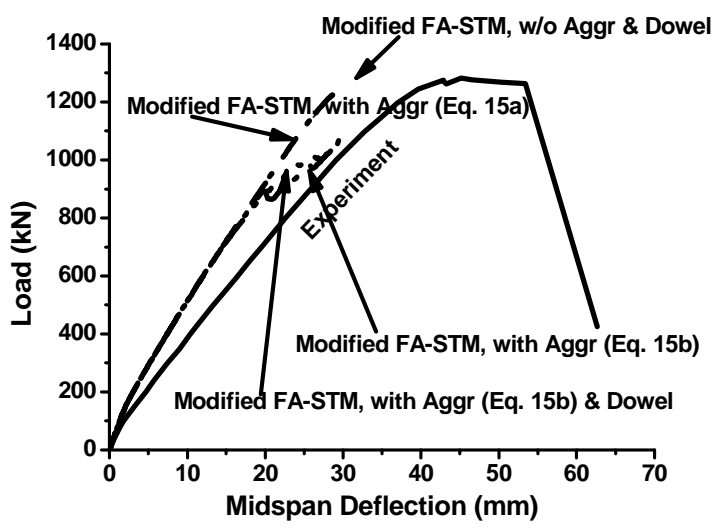

(c) VV-3.5-700

Fig. 17. Load-displacement relations of deep beams with $d=700 \mathrm{~mm}$ (continued).

\section{CONCLUSIONS}

In this paper a modified FA-STM for the analysis of the behavior of high strength reinforced concrete beams, subjected to plane stresses and monotonically loaded up to failure, is proposed. The crack angle is kept fixed at the initial direction of concrete. The functions for aggregate interlock and dowel action are used to control the shear capacity of cracked concrete. The reliability of the model has been assessed through the comparison with the experimental results. The comparison shows the aggregate interlock and dowel action can reduce the overestimation of the shear capacity of high strength reinforced beam, especially the high strength reinforced deep beam without web reinforcement. Moreover, the model is suitable for being implemented numerical procedures due its simplicity.

\section{REFERENCES}

1. Hsu, T. T. C., "Nonlinear Analysis of Concrete Membrane Elements," ACI Structural Journal, V. 88, No. 5, 1991, pp. 552-561.

2. Pang, X. B.; and Hsu T. T. C., "Behavior of Reinforced Concrete Membrane Elements in Shear," ACI Structural Journal, V. 92, No. 6, Nov.-Dec. 1995, pp. 665-679.

3. Hsu, T. T. C., "Unified Theory of Reinforced Concrete," CRC Press, Boca Raton, Florida, 1993.

4. Pang, X. B.; and Hsu, T. T. C., "Fixed-Angle SoftenedTruss Model for Reinforced Concrete", ACI Structural Journal, V. 93, No. 2, Mar.-Apr. 1996, pp. 197-207.

5. Hsu T. T. C; and Zhang, L. X., "Nonlinear Analysis of Membrane Elements by Fixed-Angle Softened-Truss Model," ACI Structural Journal, V. 94, No. 5, Sept.Oct.1997, pp. 483-492.
6. Zhang, L. X.; and Hsu, T. T. C., "Behavior and Analysis of $100 \mathrm{MPa}$ Concrete Membrane Elements," Journal of Structural Engineering, ASCE, V. 124, No. 1, Jan. 1998, pp. 24-34.

7. Aoyagi, Y.; and Yamada, K., "Strength and Deformation Characteristics of Reinforced Concrete Shell Elements Subjected to In-plane Forces," Proc. of JSCE, No. 331, 1983, pp. 167-180.

8. Kupfer, H. B.; Hilsdorf, H. K.; and Rusch, H., "Behavior of Concrete under Biaxial Stresses," ACI Journal, V. 66, No. 8, Aug. 1969, pp. 656-666.

9. Belarbi, A.; and Hsu, T. T. C., "Constitutive Laws of Softened Concrete in Biaxial Tension-Compression," ACI Structural Journal, V. 92, No. 5, Sept.-Oct. 1995, pp. 562573.

10. Belarbi, A.; and Hsu, T. T. C., "Constitutive Laws of Concrete in Tension and Reinforcing Bars Stiffened by Concrete," ACI Structural Journal, V. 91, No. 4, July-Aug. 1994, pp. 465-474.

11. Zhu, R. H.; Hsu, T. T. C.; and Lee, J. Y., "Rational Shear Modulus for Smeared-Crack Analysis of Reinforced Concrete," ACI Structural Journal, V. 98, No. 4, July-Aug. 2001, pp. 443-450.

12. Bazant, Z. P.; and Gambarova, P. M., "Rough Cracks in Reinforced Concrete," Journal of the Structural Division, Proc. of the ASCE, V. 106, No. ST4, Apr. 1980, pp. 819842

13. Paulay, T.; and Loeber, P. J., "Shear Transfer by Aggregate Interlock," ACI Special Publication SP-42, Detroit, 1974, pp. $1-15$.

14. Daschner, F.; and Kuper, H., "Test on Shear Transfer across Cracks in Normal and Light Concrete," Bauingenieur, 57, 1982, pp. 57-60.

15. CEB-FIP Model Code MC90, Committee Euro-International du Beton, Bulletin s'information Nos. 195 and 196, Mar. 1990, pp. 348.

16. Utescher, G.; and Herrmann, M., "Versuche zur Ermittlung der Tragfahigkeit in Beton eingespannter Rundsstahldollen aus nichtrostendem austenitisschem Stahl," Deutscher Ausschuss fur Stahkbton, Willhelm Ernst und Sohn, Heft 346, Berlin, 1983, pp. 49-104.

17. Vecchio, F. J.; and Collins, M. P., "The Modified Compression-Field Theory for Reinforced Concrete Elements Subjected to Shear," ACI Structural Journal, V. 83, No. 2, Mar.-Apr. 1986, pp. 219-231.

18. Baumann, T.; and Rusch, H., "Versuche zum Studium der Verdubelungswirkung der Biegezugbewehrung eines Stahlbetonbalkes," Wilhelm Ernst und Sohn, Deutscher Ausschuss fur Stahlbeton, Heft 210, Berlin, 1970.

19. Walraven, J.; and Lehwalter, N., "Size Effects in Short Beams Loaded in Shear," ACI Structural Journal, V. 91, No. 5, Sep.-Oct. 1994, pp. 585-593. 